\title{
ANALISIS DISIPLIN KERJA TERHADAP KINERJA PEGAWAI DINAS PERIKANAN DAN KELAUTAN \\ KABUPATEN KARAWANG
}

\author{
Wanta \\ Fakultas Bisnis dan Ilmu Sosial Universitas Buana Perjuangan Karawang \\ Email : wanta@ubpkarawang.ac.id; HP: 081286968419
}

\begin{abstract}
ABSTRAK
Permasalahan absensi pegawai menjadi persoalan yang perlu diperhatikan, hampir tiap bulannya terdapat pegawai yang tidak masuk kantor, dan datang terlambat namun pulang lebih cepat. Sedangkan penyerapan anggaran yang dimiliki Dinas Perikanan dan Kelautan Karawang mengalami perubahan yang tidak menentu yaitu terkadang naik dan terkadang turun, pada beberapa tahun anggaran kebelakang penyerapan anggaran mengalami penurunan yang cukup drastis, hal ini mengindikasikan kedisiplinan pegawai yang berimbas terhadap kinerja pegawai berupa penyerapan anggaran.

Penelitian ini menggunakan penelitian kuantitatif verifikatif yaitu menguji hipotesis dari kerangka berfikir. Sampel yang digunakan adalah populasi sedangkan analisis yang digunakan adalah analisis regresi linier sederhana.

Hasil penelitian menunjukan bahwa Disiplin kerja berpengaruh signifikan terhadap kinerja pegawai. Keadaan ini ditunjukan dari nilai $\mathrm{F}_{\text {hitung }}$ lebih besar dari $F_{\text {tabel }}(130,839>3,95)$ dengan tingkat signifikan $F$ lebih kecil dari nilai alpha $(\alpha)$ $(0,000<0,05)$ atau juga ditunjukan dari nilai $t_{\text {hitung }}$ lebih besar dari $t_{\text {tabel }}(11,438>$ 1,988) dengan tingkat signifikan $t$ lebih kecil dari nilai alpha $(\alpha)$.
\end{abstract}

Kata kunci: Disiplin Kerja, Kinerja Pegawai 


\section{PENDAHULUAN}

Pegawai merupakan sumber daya utama dalam menggerakan organisasi dan melaksankan tugas serta fungsinya. Pegawai terkadang dalam menjalankan tugasnya difasilitasi dengan sarana dan prasarana yang baik dan lengkap belum tentu menjamin kinerja pegawai yang efektif tanpa adanya motivasi yang tinggi, disiplin kerja pegawai serta evaluasi sebagai umpan balik atas kinerja pegawai pegawai tersebut serta kepemimpinan yang efektif dalam mengarahkan dan mengintegrasikan semua kepentingan pegawai.

Kinerja pegawai merupakan kajian yang penting untuk dikaji dalam rangka mempertahankan dan meningkatkan pelayanan publik. Menurut Mangkunegara (2011) faktor yang mempengaruhi pencapaian kinerja adalah faktor kemampuan dan faktor motivasi. Kinerja yang baik adalah kinerja yang optimal, yaitu kinerja yang sesuai standar organisasi dan mendukung tercapainya tujuan organisasi. Faktor kemampuan pegawai saja tidak akan efektif jika pegawai tidak mematuhi peraturan kepegawaian. Disiplin kerja akan menekankan pembentukan perilaku pegawai untuk mentaati peraturan yang sudah ditetapkan.

Kebanyakan pembentukan disiplin pegawai adalah salah satunya dengan absen masuk dan pulang kantor melalui alat finger print. Disiplin kerja pegawai adalah perilaku untuk menyesuaikan diri dengan tata tertib organisasi. Terwujudnya disiplin kerja akan berpengaruh terhadap rangkaian kegiatan. Disiplin kerja pegawai juga dapat pula menentukan ke arah mana rangkaian kerja dalam menuju sasaran dan tujuan organisasi. Disiplin kerja pegawai tercermin dari mematuhi dan melaksanakan tata tertib dan peraturan, masuk tepat waktu, memakai atribut organisasi, mengerjakan tugas sesuai prosedur dan sebagainya. Hal tersebut dapat mempengaruhi kinerja pegawai.

Penilaian kinerja sebagai faktor penting mengevaluasi kinerja pegawai yang dibandingkan dengan kinerja standar yang sudah ditentukan. Apabila kinerja pegawai lebih baik dari atau sama dengan kinerja standar, maka kinerja pegawai tersebut baik. Dan sebaliknya apabila kinerja pegawai dibawah standar kinerja maka kinerja tersebut buruk. Adapun penilaian kinerja dapat dijelaskan oleh penelitian Bramasari dan Siregar (2009) menjelaskan bahwa tujuan penilaian 
kinerja adalah sebagai "alat" diagnostik dan proses penilaian terhadap pengembangan individu, tim dan organisasi. Oleh karena itu kinerja merupakan suatu fungsi potensi, untuk mencapai dan mempertahankan kinerja diperlukan berbagai proses organisasional yang memungkinkan orang, maupun program mewujudkan potensi mereka sepenuhnya. Maka oleh karena itu, kebutuhan untuk mencapai dan mempertahankan kinerja menentukan target kemampuan organisasi. Kinerja juga dinilai berdasarkan tujuan organisasi secara keseluruhan yang mungkin telah dipecah menjadi beberapa target terpisah yang bersama-sama memberikan kontribusi bagi tujuan keseluruhan organisasi.

Dinas Perikanan dan Kelautan Kabupaten Karawang dibentuk melalui Peraturan Daerah Kabupaten Karawang Nomor 9 Tahun 2011, tentang Sekretariat Daerah, Sekretariat DPRD, Dinas Daerah dan Lembaga Teknis Daerah, Kecamatan dan Kelurahan. Fungsi dan rincian tugas Dinas Kelautan dan Perikanan dipimpin oleh satu Kepala Dinas yang berada dibawah tanggung jawab Bupati yang penyerahan wewenangnya melalui Sekertaris Daerah. Berdasarkan hasil observasi awal penyerapan anggaran yang dimiliki Dinas Perikanan dan Kelautan Karawang mengalami perubahan yang tidak menentu yaitu terkadang naik dan terkadang turun, pada tahun anggaran 2014 penyerapan anggaran mengalami penurunan yang cukup drastis. (Rizali Husna, 2015).

Permasalahan absensi pegawai menjadi persoalan yang perlu diperhatikan, hampir tiap bulannya terdapat pegawai yang tidak masuk kantor, dan datang terlambat namun pulang lebih cepat. (Rizali Husna, 2015) dari pernyataan tersebut bahwa diindikasikan kurang taatnya pegawai terhadap ketidakdisiplinan kerja. Penjelasan tersebut mengganggap bahwa perlu dilakukan peneltian lebih lanjut oleh peneliti tentang Analisis Disiplin Kerja terhadap Kinerja Pegawai Dinas Perikanan dan Kelautan Karawang.

\section{RUMUSAN MASALAH}

Berdasarkan fenomena dan permasalahan dalam pendahuluan maka peneliti mengungkapkan rumusan masalah yaitu bagaimana pengaruh disiplin kerja terhadap kinerja pegawai Dinas Perikanan dan Kelautan Karawang? 


\section{TUJUAN PENELITIAN}

Tujuan penelitian ini untuk menganalisis disiplin kerja terhadap kinerja pegawai Dinas Perikanan dan Kealutan Kabupaten Karawang.

\section{LANDASAN TEORI}

\section{Disiplin Kerja}

Menurut Mangkunegara (2011) disiplin diri ialah usaha seseorang untuk mengendalikan reaksi mereka terhadap keadaan yang tidak mereka senangi dan usaha seseorang untuk mengatasi ketidaksenangan itu. Menurut Simamora (2014) disiplin adalah prosedur yang mengoreksi atau menghukum bawahan karena melanggar peraturan atau prosedur. Disiplin merupakan bentuk pengendalian diri pegawai dan pelaksanaan yang teratur dan menunjukan tingkat kesungguhan tim kerja di dalam sebuah organisasi. Tindakan disipliner menuntut suatu hukuman terhadap pegawai yang gagal memenuhi standar-standar yang ditentukan.

Rivai dan Sagala (2011) berpendapat secara umum terdapat empat persepektif daftar yang menyangkut disiplin kerja yaitu :

1. Disiplin retributif, yaitu berusaha menghukum orang yang berbuat salah.

2. Disiplin korektif, yaitu berusaha membantu pegawai mengkoreksi perilakunya yang tidak tepat.

3. Perspektif hak-hak individu, yaitu berusaha melindungi hak-hak dasar individu selama tindakan-tindakan disipliner.

4. Perspektif utilitarian, yaitu berfokus kepada penggunaan disiplin hanya pada saat konsekuensi-konsekuensi tindakan disiplin melebihi dampak-dampak negatifnya.

Kerlinger dan Pedhazur (1978) menyebutkan sejumlah ciri-ciri atau indikator disiplin kerja pegawai yaitu :

1. Kepatuhan pegawai pada jam-jam kerja.

2. Kepatuhan pegawai terhadap perintah dari pimpinan serta taat pada aturan dan tata tertib yang berlaku.

3. Berpakaian seragam ke tempat kerja atau berpakaian pengenal perusahaan

4. Menggunakan dan memelihara alat-alat dan perlengkapan organisasi dengan hati-hati. 
5. Bekerja dengan mengikuti cara-cara bekerja yang telah ditentukan oleh perusahaan.

\section{Kinerja Pegawai}

Menurut Soelaiman Sukmalana (2005) bahwa kinerja adalah sebagai sesuatu yang dikerjakan dan dihasilkan dalam bentuk produk maupun jasa dalam periode tertentu dan ukuran tertentu oleh seseorang atau sekelompok orang yang didasarkan pada kecakapan, kemampuan, pengetahuan maupun pengalamanya. Menurut Fahmi (2013) kinerja adalah hasil yang diperoleh oleh suatu organisasi baik organisasi tersebut bersifat profit oriented dan non profit oriented yang dihasilkan selama satu periode tertentu. Menurut Mangkunegara (2011) kinerja pegawai adalah hasil kerja secara kualitas dan kuantitas yang dicapai oleh seorang pegawai dalam melaksanakan tugasnya dengan tanggung jawab yang diberikan kepadanya.

Sedarmayanti (2014) berpendapat bahwa setiap organisasi biasanya cenderung tertarik pada pengukuran kinerja dalam aspek berikut:

1. Aspek financial; Meliputi anggaran suatu organisasi. Karena aspek finansial dapat analogikan sebagai aliran darah dalam tubuh manusia, aspek finasial merupakan aspek penting yang perlu diperhatikan dalam pengukuran kinerja.

2. Kepuasan pelanggan; Dengan semakin banyaknya tuntutan masyarakat akan pelayanan yang berkualitas, maka organisasi dituntut terus menerus memberi pelayanan berkualitas prima.

3. Operasi bisnis internal; Informasi operasi bisnis internal diperlukan untuk memastikan bahwa seluruh kegiatan organisasi sudah seirama untuk mencapai tujuan dan sasaran organisasi seperti yang tercantum dalam rencana strategis.

4. Kepuasan karyawan; Karyawan merupakan asset yang harus dikelola dengan baik, apabila kegiatan organisasi yang banyak melakukan inovasi, peran strategi karyawan sangat nyata.

5. Kepuasan komunitas dan stakeholders; Kegiatan instansi pemerintah berinteraksi dengan berbagai pihak yang menaruh kepentingan terhadap keberadaannya. 
6. Waktu; Ukuran waktu merupakan variabel yang perlu diperhatikan dalam desain pengukuran kinerja.

Menurut Maltis dan Jackson (2002) kinerja pegawai adalah seberapa banyak mereka memberikan kontribusi kepada organisasi yang antara lain termasuk.

1. Kuantitas Keluaran; Jumlah keluaran yang seharusnya dibandingkan dengan kemampuan sebenarnya. Jumlah kuantitas keluaran harus dibandingkan dengan standar target yang ditentukan.

2. Kualitas Keluaran; Kualitas produk lebih ditamakan dibandingkan jumlah out put. Setiap produk atau pelayanan mempunyai standar mutu yang dihasil. Dalam menjalankan tugas melayani atau memproduksi produk harus berdasarkan standar mutu organisasi.

3. Jangka Waktu Keluar; Ketepatan waktu yang digunakan dalam menghasilkan sebuah barang / pelayanan.

4. Tingkat Kehadiran di Tempat Kerja; Kehadiran pegawai di tempat kerja sudah ditentukan pada awal pegawai bergabung dengan organisasi, jika kehadiran dibawah standar kerja yang ditetapkan maka pegawai tersebut tidak akan mampu memberikan kontribusi yang optimal terhadap perusahaan.

5. Kerjasama; Keterlibatan seluruh pegawai dalam mencapai target yang ditetapkan sangat penting. Kerja sama yang baik antar pegawai akan mampu meningkatkan kinerja.

Beberapa penelitian telah dilakukan tentang disiplin kerja yang mempunyai pengaruh terhadap kinerja pegawai, seperti penelitian yang dilakukan oleh Ivan Rahmat Maulana (2013) Disiplin Pegawai berpengaruh secara signifikan terhadap Kinerja Pegawai pada Bidang Kebersihan dan Pertamanan Dinas Tata Ruang, Permukiman dan Kebersihan Kabupaten Subang. Bahwa secara menyeluruh Disiplin Pegawai telah dilaksanakan dan dijadikan sesuai dengan faktor-faktor Kinerja Pegawai.

76. 


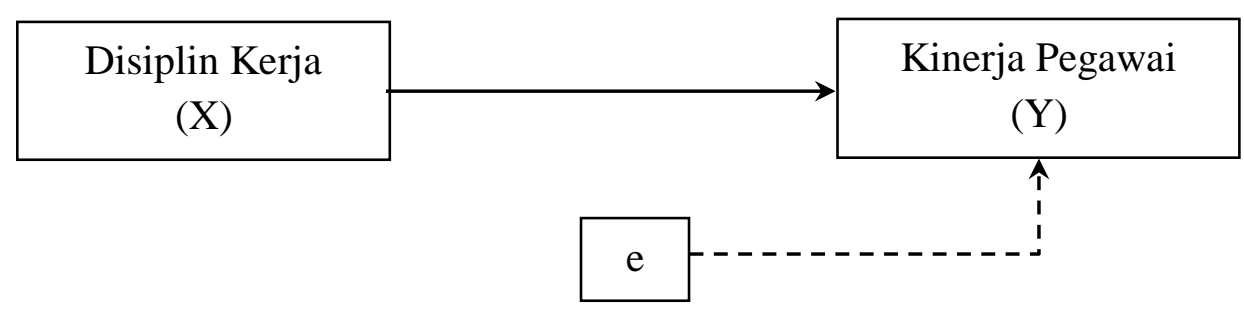

Gambar 1.1

Kerangka Berpikir Penelitian

Maka hipotesis penelitian ini yaitu terdapat pengaruh disiplin kerja terhadap kinerja pegawai Dinas Perikanan dan Kelautan Karawang.

\section{DESAIN PENELITIAN}

Desain Penelitian ini menggunakan penelitian kuantitatif verifikatif yaitu penelitian kuantitatif untuk menguji hipotesis berupa analisis disiplin kerja terhadap kinerja pegawai dengan menggunakan alat uji statistik.

Penentuan data primer diambil dari populasi penelitian yaitu populasi atau pegawai dari Dinas Perikanan dan Kelautan Kabupaten Karawang sebanyak 85 orang.

\section{METODE ANALISIS DATA}

Analisis yang digunakan adalah analisis regresi linier sederhana untuk menguji apakah ada pengaruh antara variabel bebas (disiplin kerja) terhadap variabel terikat (kinerja pegawai). Analisis regresi linier dalam penelitian ini dengan menggunakan metode regression linear-analysis, hasil analisis dapat dilihat pada out put model summary, model anova dan model coefficients dengan software SPSS.

\section{HASIL DAN PEMBAHASAN}

\section{Disiplin Kerja}

Uji validitas variabel disiplin kerja $(\mathrm{X})$ diperoleh nilai Sig. (2-tailed / $0,000)$ lebih kecil dari alpha $(\alpha=5 \%$ atau 0,05$)$ dengan tingkat kepercayaan $95 \%$. Hal tersebut menunjukan bahwa pertanyaan-pertanyaan yang terdapat pada 
variabel disiplin kerja (X) dinyatakan valid dan dapat digunakan untuk pengolahan data selanjutnya dalam penelitian ini.

Hasil uji reliabilitas variabel disiplin kerja (X) dengan menggunakan cronbach's alpha if item deleted. Jumlah nilai cronbach's alpha if item deleted variabel disiplin kerja $(X)$ sebesar 0,938, nilai tersebut lebih besar dari nilai $r_{\text {tabel }}$ $(0,179$ pada lampiran) untuk df $=85-2=83$ dengan tingkat signifikansi $5 \%$. Sehinga butir-butir pertanyaan variabel disiplin kerja $(\mathrm{X})$ dinyatakan reliabel dan dapat dipergunakan pada instrumen penelitian berikutnya.

\section{Kinerja Pegawai}

Uji validitas variabel kinerja pegawai (Y) diperoleh nilai Sig. (2-tailed / $0,000)$ lebih kecil dari alpha $(\alpha=5 \%$ atau 0,05$)$ dengan tingkat kepercayaan 95\%. Hal tersebut menunjukan bahwa pertanyaan-pertanyaan yang terdapat pada variabel kinerja pegawai (Y) dinyatakan valid dan dapat digunakan untuk pengolahan data selanjutnya dalam penelitian ini.

Hasil uji reliabilitas variabel Kinerja Pegawai (Y) dengan menggunakan cronbach's alpha if item deleted.Jumlah nilai cronbach's alpha if item deleted variabel kinerja pegawai (Y) sebesar 0,930, nilai tersebut lebih besar dari nilai $\mathrm{r}_{\text {tabel }}(0,179$ pada lampiran $)$ untuk $\mathrm{df}=85-2=83$ dengan tingkat signifikansi $5 \%$. Sehinga butir-butir pertanyaan variabel kinerja pegawai (Y) dinyatakan reliabel dan dapat dipergunakan pada instrumen penelitian berikutnya.

\section{Analisis Regresi}

Hasil analisis korelasi disiplin kerja dengan kinerja pegawai terlihat pada tabel berikut ini :

Tabel 1.1

Analisis Korelasi Disiplin Kerja dengan Kinerja Pegawai

\begin{tabular}{|ll|r|r|}
\multicolumn{2}{|c|}{ Correlations } \\
\hline & & $\begin{array}{r}\text { Kinerja Pegawai } \\
(\mathrm{Y})\end{array}$ & $\begin{array}{c}\text { Disiplin Kerja } \\
(\mathrm{X})\end{array}$ \\
\hline \multirow{2}{*}{ Pearson Correlation } & Kinerja Pegawai (Y) & 1,000 &, 782 \\
Sig. (1-tailed) & Disiplin Kerja (X) &, 782 & 1,000 \\
& Kinerja Pegawai (Y) &, 000 &, 000 \\
N & Disiplin Kerja (X) & 63 & 63 \\
& Kinerja Pegawai (Y) & 83 & 63 \\
\hline
\end{tabular}

Sumber : Hasil Pengolahan Data Tahun 2017

78. 
Berdasarkan data pada tabel tersebut, korelasi disiplin kerja dengan kinerja pegawai yaitu sebesar 0,782, nilai korelasi tersebut berada pada daerah kuat $(0,600-0,799=$ kuat $)$ dan positif (searah) atau dapat dikatakan bahwa korelasi atau hubungan disiplin kerja dengan kinerja pegawai mempunyai tingkat hubungan kuat dan searah (positif).

Analisis regresi linier mengenai pengaruh disiplin kerja (X) terhadap kinerja pegawai (Y) diperoleh hasil sebagai berikut :

Tabel 1.2

Analisis Regresi Linier Model Summary

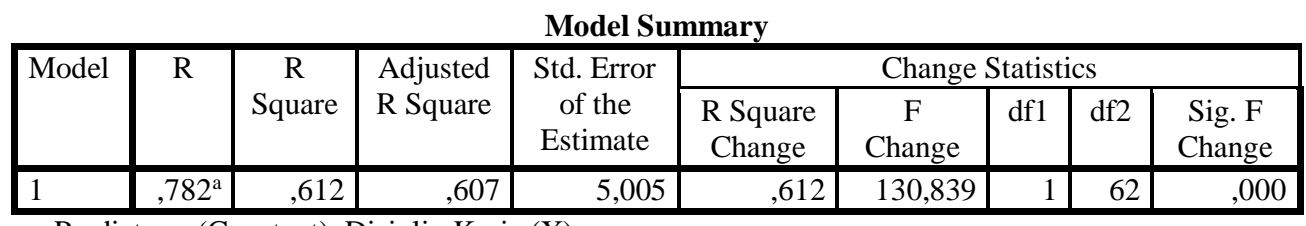

a. Predictors: (Constant), Disiplin Kerja (X)

Sumber : Hasil Pengolahan Data tahun 2017

Data pada tabel tersebut diperoleh keluaran nilai koefisien korelasi (R) sebesar 0,782 atau $\mathrm{R}>0$, artinya bahwa terdapat hubungan kuat $(0,600-0,799=$ kuat) antara disiplin kerja dengan kinerja pegawai. Hasil keluaran nilai koefisien determinasi ( $\mathrm{R}$ Square atau $\mathrm{R}^{2}$ ) sebesar 0,612 atau 61,2\%. Nilai tersebut menunjukan kemampuan variabel disiplin kerja $(\mathrm{X})$ menjelaskan variansi pada variabel kinerja pegawai (Y) sebesar $61,2 \%$ dan sisanya sebesar $38,8 \%$ dipengaruhi oleh faktor lain (e) yang tidak diikutsertakan dalam penelitian ini. Faktor lain tersebut seperti pemberian kompensasi, budaya organisasi, motivasi kerja, prestasi kerja dan lain-lain.

Hasil keluaran regresi linier model anova terlihat pada tabel berikut ini :

Tabel 1.3

Analisis Regresi Linier Model Anova

ANOVA $^{\mathrm{a}}$

\begin{tabular}{|rl|r|r|r|r|r|}
\hline Model & & Sum of Squares & Df & Mean Square & F & \multicolumn{1}{c|}{ Sig. } \\
\hline \multirow{2}{*}{1} & Regression & 3277,370 & 1 & 3277,370 & 130,839 &, $000^{\mathrm{b}}$ \\
& Residual & 2079,054 & 62 & 25,049 & & \\
& Total & 5356,424 & 63 & & & \\
\hline
\end{tabular}

a. Dependent Variable: Kinerja Pegawai (Y)

b. Predictors: (Constant), Disiplin Kerja (X)

Sumber : Hasil Pengolahan Data Tahun 2017 
Data pada tabel tersebut diperoleh nilai signifikansi $\mathrm{F}$ sebesar $0,000(\mathrm{P}-$ value) artinya bahwa variabel disiplin kerja (X) berpengaruh signifikan terhadap variabel kinerja pegawai (Y). Atau dengan memperhatikan nilai $F_{\text {hitung }}(130,839)$ yang mempunyai nilai lebih besar dari nilai $F_{\text {tabel }}(3,95)$ atau $130,839>3,95$ yang berarti bahwa variabel disiplin kerja $(\mathrm{X})$ berpengaruh terhadap variabel kinerja pegawai (Y).

Hasil analisis regresi linier model coefficients terlihat pada tabel berikut ini :

Tabel 1.4

Analisis Regresi Linier Model Coefficients

\begin{tabular}{|c|c|c|c|c|c|c|}
\hline \multicolumn{7}{|c|}{ Coefficients $^{\mathbf{a}}$} \\
\hline \multirow[t]{2}{*}{ Model } & & \multicolumn{2}{|c|}{$\begin{array}{c}\text { Unstandardized } \\
\text { Coefficients }\end{array}$} & $\begin{array}{l}\text { Standardized } \\
\text { Coefficients }\end{array}$ & \multirow[t]{2}{*}{$\mathrm{T}$} & \multirow[t]{2}{*}{ Sig. } \\
\hline & & $\mathrm{B}$ & Std. Error & Beta & & \\
\hline \multirow{2}{*}{1} & (Constant) & 11,729 & 4,401 & & 2,665 & ,009 \\
\hline & Disiplin Kerja (X) & ,736 & ,064 & ,782 & 11,438 & ,000 \\
\hline
\end{tabular}

Sumber : Hasil Pengolahan Data Tahun 2017

Berdasarkan data pada tabel di atas diperoleh persamaan regresi linear sebagai berikut :

$$
\mathrm{Y}=11,729+0,736 \mathrm{X}+\mathrm{e}
$$

Dari persamaan regresi linier tersebut dapat dideskripsikan sebagai berikut :

a. Nilai koefisien sebesar 11,729 adalah nilai koefisien kinerja pegawai (Y) saat disiplin kerja (X) sama dengan nol (0).

b. Nilai sebesar 0,736 pada koefisien $\mathrm{X}$ yaitu jika disiplin kerja $(\mathrm{X})$ naik sebesar 1 satuan unit skor, maka kinerja pegawai (Y) akan naik sebesar 0,736.

\section{Pengaruh Disiplin Kerja terhadap Kinerja Pegawai pada Dinas Perikanan dan Kelautan Karawang}

Nilai $F_{\text {hitung }}$ disiplin kerja $(X)$ lebih besar dari nilai $F_{\text {tabel }}(130,839>3,95)$ atau tingkat signifikansi $\mathrm{F}$ lebih kecil dari nilai alpha $(0,000<0,05)$, dengan demikian bahwa variabel disiplin kerja (X) berpengaruh signifikan terhadap variabel kinerja pegawai (Y).

Nilai $t_{\text {hitung }}$ disiplin kerja $(X)$ lebih besar dari $t_{\text {tabel }}(11,438>1,988)$ atau tingkat signifikansi thitung lebih kecil dari nilai alpha $(0,000<0,05)$, dengan 
demikian bahwa terjadi penolakan $\mathrm{H}_{0}$ atau penerimaan $\mathrm{H}_{\mathrm{a}}$ yang berarti menunjukan adanya pengaruh variabel disiplin kerja (X) secara signifikan terhadap variabel kinerja pegawai (Y).

\section{KESIMPULAN}

Kesimpulan dari hasil penelitian mengenai pengaruh disiplin kerja terhadap kinerja pegawai Dinas Perikanan dan Kelautan Karawang yaitu disiplin kerja berpengaruh signifikan terhadap kinerja pegawai. Keadaan ini ditunjukan dari nilai $F_{\text {hitung }}$ lebih besar dari $\mathrm{F}_{\text {tabel }}(130,839$ > 3,95) dengan tingkat signifikan $\mathrm{F}$ lebih kecil dari nilai alpha $(\alpha)(0,000<0,05)$ atau juga ditunjukan dari nilai $t_{\text {hitung }}$ lebih besar dari $t_{\text {tabel }}(11,438>1,988)$ dengan tingkat signifikan $t$ lebih kecil dari nilai alpha $(\alpha)$.

\section{DAFTAR PUSTAKA}

Brahmasari, Ida Ayu. dan Parniel Siregar. 2009. Pengaruh Budaya Organisasi, Kepemimpinan Situasional dan Pola Komunikasi terhadap Disiplin Kerja dan Kinerja Karyawan pada PT Central Proteinaprima Tbk. JURNAL Aplikasi Manajemen, Vol 7 No 1.

Fahmi, Irham. 2013. Manajemen Kinerja Teori dan Aplikasi. Bandung: Alfabeta.

Mangkunegara, Anwar Prabu. . 2011. Manajemen Sumber Daya Manusia Perusahaan.Bandung: Remaja Rosda karya.

Mathis Robert, Jackson John. 2002. Manajemen Sumber Daya Manusia. Jakarta: Salemba empat.

Maulana, Ivan Rahmat. 2013. Pengaruh Disiplin Pegawai Terhadap Kinerja Pegawai Pada Bidang Kebersihan dan Pertamanan Dinas Tata Ruang Permukiman dan Kebersihan Kabupaten Subang.

Peraturan Daerah Kabupaten Karawang Nomor 9 Tahun 2011, tentang Sekretariat Daerah, Sekretariat DPRD, Dinas Daerah dan Lembaga Teknis Daerah, Kecamatan dan Kelurahan.

Rivai, Veithzal. Dan Ella Jauvani Sagala. 2011. Edisi Kedua Manajemen Sumber Daya Manusia untuk Perushaan dari Teori ke Praktik. Jakarta: Rajawali Pers. 
Rizali Husna. 2015. Pengaruh Peran Kepemimpinan dan Budaya Organisasi Terhadap Kinerja Pegawai Pada Dinas Perikanan dan Kelautan Kabupaten Karawang. Karawang. Unsika.

Sedermayanti. 2014. Manajemen Sumberdaya Manusia Reformasi Birokrasi dan Manajemen Pegaawai Negeri Sipil. Bandung: Refika Aditama.

Soelaiman Sukmalana. 2005. Evaluasi Kinerja. Program PPS UTP. 